\title{
The effect of ethanol extract of sarang semut plant (Hypnophytum formicarum) to angiogenesis for wound healing after teeth extraction experimental research on marmot (Cavia cobaya)
}

\author{
Sartika Amelia Putri ${ }^{*}$ Efa Ismardianita** \\ *Department of Oral Surgery, Faculty of Dentistry, Universitas Baiturrahmah, Padang, Indonesia
}

\begin{abstract}
Introduction: Tooth extraction causing injuries, to accelerate wound healing was given medication. Drugs commonly used for wound healing after tooth extraction is povidone iodine act as bacteriostatic for all germs. Excessive use of povidone iodine can cause side effects such as itching, pain in the area around the wound, swelling and dermatitis, so it sought a safe substitute drugs derived from herbs. One of the herbs are often used by people in the Mentawai Islands is a sarang semut's root species of Hypnophytum formicarum. Methods: This study aimed to determine the effect of sarang semut's extract orally for angiogenesis in wound healing after tooth extraction. This research is experimental with posttest only control group design. Subjects were 48 -animal marmots were divided into 4 groups, will be deprived of his left mandibular insisivus. Group I (control 0.5\% CMC, treatment group II, III, IV with 4.65 $\mathrm{mg}$, and $9.3 \mathrm{mg} \mathrm{6,2} \mathrm{mg}$ dose tuber ethanol extract dissolved anthill in CMC 0.5\%), were given $3 \mathrm{ml}$ orally, 3 times a day until the day of decapitation. Futher histological preparations made by HE staining and the observed area is apex, medial, servical, and lateral used 400x magnification. The data was analyzed with parametric test One-Way ANOVA, and to see the significance between dose used LSD test. Result: The results showed that the extract of sarang semut has an effect $(p<0.05)$ on the angiogenesis in wound healing after tooth extraction. The most effective concentration was $4.65 \mathrm{mg}$. Conclusion: It can be concluded that there was influences of ethanol extract of ant nest tuber (Hydnophytum formicarum) to angiogenesis wound healing process after extraction of marmot (Cavia cobaya).
\end{abstract}

Keywords: Extract ethanol, Hypnophytum formicarum, angiogenesis, tooth extraction.

\section{INTRODUCTION}

Tooth extraction is one of the most common acts, the result of which results in injury. Injury is a breakdown of normal anatomic structures and tissue functions followed by cellular disorders that cause loss of vein continuity, resulting in a direct connection between the extravascular and intravascular. ${ }^{1}$

Wound healing after tooth extraction consists of inflammatory phases, proliferative phases and remodeling phases. ${ }^{2}$ In the proliferation phase there is the formation of inflammatory cells (dominated by macrophages), fibroblasts, 
and the formation of new blood vessels or angiogenesis. ${ }^{3}$ The tissue damage that occurs after tooth extraction leads to the release of growth factor by platelets. Growth factors released by platelets are PDGF, VEGF, TGF- $\alpha$, TGF-B, PD-ECGF, and angiopoietin-1 produced by epidermal cells, fibroblasts, macrophages, vascular endothelial cells, and osteoblasts. ${ }^{4}$ PDGF and VEGF simultaneously trigger angiogenesis and mediate blood vessel growth. VEGF also plays a role in increasing vascular permeability, whereas PDGF plays a role in facilitating vascular maturation. ${ }^{5}$

The formation of new blood vessels or angiogenesis is one of the key elements in the wound healing process. The blood vessels carry the oxygen and nutrients necessary for cell survival. ${ }^{6.7}$ The formation of new blood vessels or angiogenesis begins on the $2^{\text {nd }}$ day and lasts until the $21^{\text {st }}$ day of which the peak occurs from day $5 .{ }^{8}$

Wound healing after tooth extraction can be accelerated with drug administration. Drugs used are antiseptics that can kill bacteria and prevent bacteremia, behind the excess antiseptics have a variety of adverse effects. ${ }^{9}$ Therefore, research to find a replacement drug, by switching to medicinal plants. Ant nest tubers (Hypnophytum formicarum) is one of medicinal plants, the people of Mentawai Island often use this plant to treat various diseases.

According to phytochemical test extract of ant nest tuber plants containing flavonoids, tannins, tocopherols, and alkaloids. ${ }^{10}$ Flavonoids as antibacterial, anti-inflammatory, and antioxidant. Tanin as hemostatic and astrigen while alkaloids as analgesic. ${ }^{11}$ The purpose of this research is to know the effect of ethanol extract of ant nest bulb on angiogenesis formation on wound healing process after experimental teeth extraction.

\section{METHODS}

This study was purely experimental design with posttest only control group design. This research was carried out at: Laboratorium Herbarium Universitas Andalas, this herb belongs to Family: Rubiaceae with species: Hydnophytum formicarum jack (SK No. 037/K-ID/YOU/II/2016). Preparation of extracts and phytochemical test was performed at Laboratorium Kimia Universitas Padjadjaran and this extract's herb was known containing flavonoids, triterpeneoid, phenols, and tannins. Teeth extraction, coloring, and histological observations were performed in LPPT Unit IV, and Laboratorium Patologi Anatomi Fakultas Kedokteran, Universitas Gajah Mada. This study starts from April to July 2016. The study declared eligible conduct by Komisi Etik Penelitian Fakultas Kedokteran Universitas Andalas (SK No. 073/KEP/FK/2016).

The extract of sarang semut's root was obtained by peeling the root, sliced thinly (3-5 $\mathrm{mm}$ ), dried in oven (temp $50^{\circ} \mathrm{C}$ ) to obtain the dry root and easily broken for, then blended up into a coarse powder escaped sieve no. $30.11 \mathrm{~A}$ total of $1000 \mathrm{~g}$ of dry powder sarang semut's root was marinated with $70 \%$ ethanol with a ratio of 1:5. Maceration was carried out by shaking the first 6 hours and placed for 18 hours. Maceration was performed over and over until the filtrate obtained discolored. Furthermore, the filtrate evaporated with a rotary evaporator (temp $500^{\circ} \mathrm{C}$ ), and put into the oven until all the water evaporates and becomes dry extract, to obtain a thick extract with fixed weights (not dripping).

Determination of dose, Dose of sarang semut's extract was given to humans as powder as 1500-3000 mg/day (1-2 capsules @ $500 \mathrm{mg}$, three times daily) (Suryajaya, 2013). The dose used in this study is based on a conversion scale doses of human (70 kg) to guinea pigs weighing 400 grams is 0,031. Dose I: $4.65 \mathrm{mg} / 400 \mathrm{~g} \mathrm{~mm} /$ day; Dose II: 6.2 $\mathrm{mg} / 400 \mathrm{~g} \mathrm{~mm} /$ day; Dose III: $9.3 \mathrm{mg} / 400 \mathrm{~g} \mathrm{~mm} /$ day.

Preparation of Animal Test and Tooth extraction, Population for this study is male guinea pigs. The sample is a part of the population that according to the inclusion and exclusion criteria. Inclusion criteria: male guinea pigs, weighing 250400 grams, aged 6-8 weeks. Exclusion criteria: guinea pigs had ever sick and died during the treatment. The sample size is determined by the formula Federer $(t-1)(n-1) \geq 15$. Because there are four groups (control, dose I, II, III) with observation time (days 3, 7,14, and 21), the sample size used was 48-animal guinea pigs, consists of 3 guinea pigs respectively. The independent variables: sarang semut's root extract and dependent variables: the angiogenesis. Guinea pigs have adapted for one week, then anesthetized IM with ketamine $(0.1 \mathrm{ml})$ and zylazin $(0.1 \mathrm{ml})$. After tooth extraction on control group (I) given CMC $0.5 \%$, the 
Table 1. Assesment of research parameters.

\begin{tabular}{lc}
\hline Variable & Score \\
\hline Angiogenesis & \\
Not finding & 0 \\
Less (focal) & 1 \\
Moderate (rare diffusion) & 2 \\
Many (masif, diffusion, hard) & 3 \\
\hline
\end{tabular}

Table 2. Result One-Way Anova test.

\begin{tabular}{ccc}
\hline Angiogenesis & Significancy limit & $\begin{array}{l}\text { Significancy value } \\
\text { p-value }\end{array}$ \\
\hline Day-1 & & 0.000 \\
Day-7 & 0.05 & 0.001 \\
Day-14 & & 0.002 \\
Day-21 & & 0.000 \\
\hline
\end{tabular}

treatment group was given a dose of the sarang semut's root extraction I, II, and III $3 \mathrm{ml}$ orally using a gastric's explorer three times a day, until the day of decapitation. Socket tissues were taken and fixed in $10 \%$ buffered formalin, furthermore it processing for preparing for histological by $\mathrm{HE}$ coloring. Data obtained by assessing the formation of angiogenesis using a light microscope with 400x magnification, an area that is observed starting from the apex, medial, basal, and lateral with this following criteria:

The formation of angiogenesis was assessed by anatomical pathologist and investigator. All data tabulated by group then calculated mean (mean) for each group. The statistical test used the One-Way Anova parametric hypothesis test and continued with LSD test to see the doserelated significance. The difference is significant if $p \leq 0.05$.

\section{RESULT}

Results of phytochemical test for sarang semut's root (Hypnophytum formicarum) of the Mentawai Islands, is containing phenols, flavonoids, triterpenoids and Tannin. The formation of angiogenesis.was assessed by observing total.

Then, data were analyzed with the ShapiroWilk normality test and homogeneity test with Levene Test. Obtained from the second test $p>0,05$. That means data normally distributed and was homogeneous. Based on the table, we can make a conclusion there is the influence of ethanol

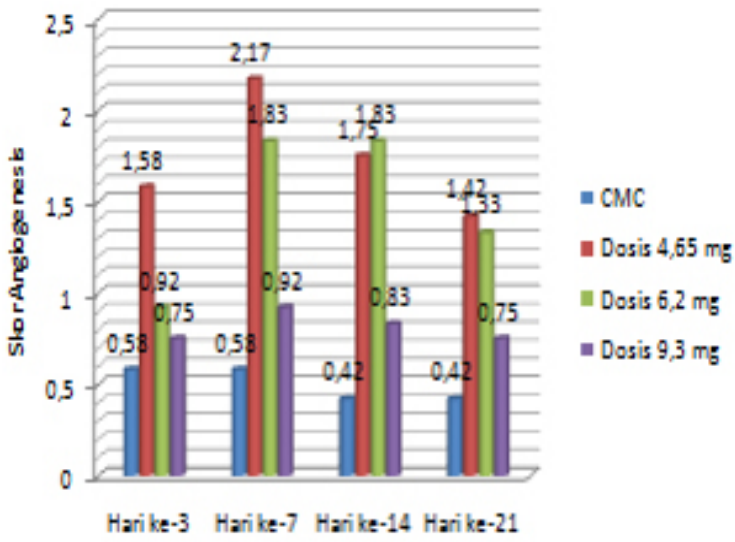

Figure 1. The result of statistical test using One-Way Anova test in all treatment day group.

extract of sarang semut's root (Hydnophytum formicarum) to angiogenesis. To see the effect ethanol extract of the root of sarang semut, this analysis followed by One Way Anova test:

The result of statistical test using One-Way Anova test showed that significance value of $p<0,05$ in all treatment day group, it can be concluded that there is an effect of ethanol extract of ant nest tuber (Hydnophytum formicarum) orally to the formation of angiogenesis in wound healing process after repeal Marmot (Cavia cobaya) on day 3, 7, 14 and 21 using CMC, $4.65 \mathrm{mg}$ dose; $6.2 \mathrm{mg}$; 9.3mg. (Figure 1)

After the One-Way Anova test then continued with LSD follow-up test to determine thesignificance differences between doses of each group. Based on the results of the research on the 3rd day obtained a significant different CMC with a dose of $4.65 \mathrm{mg}$, and a dose of $6.2 \mathrm{mg}$.

Dose $4.65 \mathrm{mg}$ differed significantly with a dose of $6.2 \mathrm{mg}$ and a dose of $9.3 \mathrm{mg}$. At a dose of $6.2 \mathrm{mg}$ different and not significant with a dose of $9.3 \mathrm{mg}$. The dose of $9.3 \mathrm{mg}$ is different and not significant with CMC.

Based on the results of the research on the $7^{\text {th }}$ day obtained by CMC was significantly different with the dose $4.65 \mathrm{mg}, 6.2 \mathrm{mg}$ dose. The dose of $4.65 \mathrm{mg}$ was significantly different with the dose of $9.3 \mathrm{mg}$. At a dose of $6.2 \mathrm{mg}$ was significantly different with a dose of $9.3 \mathrm{mg}$. The dose of 9.3 $\mathrm{mg}$ was significantly different and not significant with CMC.

Based on the results of the research on day 14 obtained a significant different CMC with a dose 
of $4.65 \mathrm{mg}$ and a dose of $6.2 \mathrm{mg}$. The dose of 4.65 $\mathrm{mg}$ was significantly different with the dose of 9.3 $\mathrm{mg}$. At a dose of $6.2 \mathrm{mg}$ was significantly different with a dose of $9.3 \mathrm{mg}$. The dose of $9.3 \mathrm{mg}$ was significantly different and not significant with CMC.

Based on the results of the research on the $21^{\text {th }}$ day obtained a significant different CMC with a dose of $4.65 \mathrm{mg}$, dose $6.2 \mathrm{mg}$ and dose $9.3 \mathrm{mg}$. The dose of $4.65 \mathrm{mg}$ was significantly different with the dose of $9.3 \mathrm{mg}$. At a dose of $6.2 \mathrm{mg}$ was significantly different with a dose of $9.3 \mathrm{mg}$. The dose of $9.3 \mathrm{mg}$ was significantly different with the dose of CMC.

So the result of statistical test based on LSD test value known there is difference of angiogenesis formation between control group with dose group $4,65 \mathrm{mg}$, dose $6,2 \mathrm{mg}$ and dose $9,3 \mathrm{mg}$ on day 3 , day 7 , day 14 , And day 21 , so the alternative hypothesis in this study is accepted.

\section{DISCUSSION}

Statistical test results using One-Way Anova test obtained $p$ value $<0.05$. It can be concluded that there is an effect of ethanol extract of ant nest bulb (Hydnophytum formicarum) to angiogenesis on wound healing process after marmot tooth extraction (Cavia cobaya) on the 3rd, 7th, 14th and 21st day and most angiogenesis formation Much is at a dose of $4.65 \mathrm{mg}$, this indicates that at that dose the activity of the formation of new blood vessels has the highest activity.

In a study conducted, at a dose of $4.65 \mathrm{mg}$ increased the number of blood vessels on day 3 and 7 then declined on day-to-14 and to-21. The increase is caused when the tissue is damaged, the release of angiogenesis factor that will begin to bind to the endothelial cell receptor to accommodate the formation of blood vessels. Shortly after the wound, there healing process, begins with the formation of blood clots on the surface of the wound. After that, there was an inflammatory reaction on the wound edges. ${ }^{3}$

The increase is also due to the active compound content of ant nest tubers that can accelerate wound healing such as flavonoids, tannins, and triterpenoids. Flavonoids function to increase expression of insulinlike growth factor-1 (IGF-1) receptor as mediator of fibroblast proliferation and collagen synthesis. ${ }^{11}$
In addition, flavonoids can also be used as a vasculoprotector agent which is an agent to improve venous blood circulation by increasing vascular tone and reducing edema. ${ }^{12}$

Flavonoids as antibacterials form complex compounds against extracellular proteins that interfere with the integrity of bacterial cell membranes. Flavonoids as antioxidants can inhibit the clumping of blood cell cells, stimulate the production of nitric oxide for vasoconstriction of blood vessels, and inhibit the growth of cancer cells. The presence of flavonoids also serves to limit the release of inflammatory mediators. ${ }^{13}$

Flavonoids are also able to reduce the inflammatory process. The inflammatory stage causes neutrophil migration, then progresses to the wound area in this case especially on the extraction socket replaced by monocytes. Flavonoids have the ability to inhibit the action of arachidonic acid through lipooksiganase and cyclooxygenase pathways, followed by inhibition of the production of inflammatory mediators of prostaglandins, thromboxane and leucorrhenes as inflammatory mediators, so that leukocytes to the inflammatory area decrease and may accelerate the healing process. ${ }^{14}$ So the properties possessed by this flavonoid is highly considered in the process of wound healing.

The content of other bioactive compounds that play a role in wound healing is tannin by increasing the regeneration of new tissues. Tannins can heal wounds and reduce scar formation by inhibiting formation and eliminating reactive oxygen substances. ${ }^{15}$ Tannin also serves as an astrigen that causes shrinkage of the skin or mucosa pores, harden the mucosa, stop the exudate, stop light bleeding. ${ }^{15}$

On day 14 and 21 there was a decrease in dose $4.65 \mathrm{mg}$, meaning the formation of new blood vessels has been reduced. The decrease in the number of blood vessels is due to decreased factor VEGF, TGF-B, and $b-F_{\text {FG. }}{ }^{16}$ The decline occurs because the process of angiogenesis has entered the final stage, namely suppression of angiogenesis. Suppression of angiogenesis occurs because the new tissue that is formed has reached normoxia, so that new blood vessels are no longer needed. After being suppressed, newly formed blood vessels will be regenerated and the endothelial cells in them will have apoptosis. ${ }^{5}$ 
At a dose of $6.2 \mathrm{mg}$ on day 3 and 7th day increased and then stabilized at day 14 and decreased on day 21 , an increase in the number of blood vessels signifies the progress of the wound healing process in the proliferation phase. Broadly speaking the processes occurring in this phase include, re-epithelization, fibroplasia, wound contraction, and neovascularization. This increase in blood vessels is due to the high number of blood vessels affected by the number of macrophages. Macrophages secrete an angiogenesis factor (AGF) that stimulates the formation of the epithelial end of the blood vessels. Macrophages and AGF together speed up the healing process. Macrophages also produce FGF (Fibroblast Growth Factor) which stimulates endothelial cell migration and proliferation for the formation of new vessels. ${ }^{17}$

In the inflammatory stage, macrophages begin to enter the blood clot to destroy debris, bacteria, and function as phagocytosis, macrophages also play a role in releasing various growth factors such as basic fibroblast growth factor (b-FGF), transforming growth factor (TGF- B), and VEGF. The increasing number of blood vessels is also caused by the angiogenesis process continues along with the incorporation of endothelial cells with existing blood vessels to strengthen the blood vessels. ${ }^{3}$

At a dose of $6.2 \mathrm{mg}$ at day 14 is stable and decreases by 21 days, it is because the wound healing proliferation phase is nearing the beginning of the maturation phase, in which the role of capillaries in providing nutrients for cell regeneration during the wound healing period begins to diminish, Besides the growth factor has been enough to perform the task as a blood supply containing nutrients, so that the wound began to close. ${ }^{16}$ The normal formation of new blood vessels occurs on the $2^{\text {nd }}$ day until the $3^{\text {rd }}$ week after the wound, which peak occurs on the $5^{\text {th }}$ day. ${ }^{8}$ until it will eventually decrease and stabilize when the extracellular matrix begins to fill the lost region due to injury Day $14 .{ }^{18}$

The dose of $9.3 \mathrm{mg}$ of new blood vessel formation was less than the dose of $4.65 \mathrm{mg}$ and $6.2 \mathrm{mg}$. The dose of $9.3 \mathrm{mg}$ was the highest dose in this study, indicating that at higher doses, the destruction of extracellular matrix decreases so that endothelial cell proliferation also decreases.
As a result the angiogenesis process also decreases. ${ }^{19}$

Another possibility is that a dose of 9.3 $\mathrm{mg}$ is a toxic dose. According to Yuhernita ${ }^{19}$ it happens because bioactive compounds do not always provide pharmacological effects sometimes active compounds reduce activity. A considerable amount of extract has the potential to decrease the activity of the active substance, ie the cytotoxic effect of the antidial ingredients of various ant nests to the tumor cells. At high concentrations, in addition to the presence of a substantial amount of active ingredient in the extract, there are also other substances that may also be large enough in the extract. The presence of these substances can inhibit the activity of the active substance, so the effectiveness of the active substance will be disrupted. This is often found in the activity of natural material extract which is a multicomponent mixture. The effects of these components can be synergistic, additive or antagonistic.

While the control group showed no significant change, the formation of angiogenesis was lower than the treatment group. On the $3^{\text {rd }}$ day and $7^{\text {th }}$ day is stable, then decreased and stabilized again from day 14 to day 21 this may be caused by the absence of active ingredients so that the wound healing process is longer and the number of blood vessels is less. Another thing that is very likely because of the presence of microbes and tissue damage that must be phagocytes by cells in the wound. ${ }^{8}$

Based on this result, the researcher's analysis on this research is proved that ants bulb ethanol extract (Hydnophytum formicarum jack) has an effect on the formation of angiogenesis in wound healing process after the removal of marmot tooth (Cavia cobaya).

The new blood vessels in this wound area serve as a transport for the food and oxygen supply required by repair cells to destroy residual substances and form granulation tissues. They can also be helped by using ant nest bulb extracts that have previously identified bioactive components. ${ }^{19}$ 


\section{CONCLUSIONS}

It can be concluded that there was influences of ethanol extract of ant nest tuber (Hydnophytum formicarum) to angiogenesis wound healing process after extraction of marmot (Cavia cobaya).

\section{REFERENCES}

1. Guo S, DiPietro LA. Factors affecting wound healing. J Dent Res 2010;89:219-29.

2. Mackay N, Miller A. Nutritional support for wound healing. Altern Med Rev 2003;8(4):35972.

3. Kumar V, Abbas AK, Fausto N. Robbins and Cotran's pathologic basis of disease. $7^{\text {th }}$ ed. Philadelphia: Saunders; 2003.

4. Diegelmann RF, Evans MC. Wound healing: an overview of acute, fibrotic, and delayed healing. Frontiers in Bioscie 2004;9:283-9.

5. Li WW, Tsakayannis D, Li VW. Angio-genesis: A control point for normal and delayed wound healing. In: Angiogenesis in wound healing. Supplement Contemp Surg; 2003. p. 5-12.

6. Werner S, Grose R. Regulation of wound healing by growth factors and cytokines. Physiol Rev 2002;83:835-70.

7. Scrementi ME, Ferreira AM, Zender C, DiPietro LA. Site-spesific production of TGF-beta in oral mucosal and cutaneous wounds. Wound Repair Regen 2008;16(1):80-6.

8. Setiawan, Muhammad Reza, Dewi, Nurdiana, Oktaviyanti, Ika Kustiyah. Ekstrak ikan Haruan (Channastriata) meningkatkan jumlah neokapiler pada penyembuhan luka. J Dentofasial 2015;14(1)Feb:1-5.

9. Dorri M, Shahrabi S, Navabazam A. Comparing the effects of chlorhexidine and persica on alveolar bone healing following tooth extraction in rats, a randomised controlled trial. Clin Oral Investig 2012 Feb:16(1):25-31.

10. Subroto MA, Saputro H. Gempur penyakit dengan sarang semut. Jakarta: Penebar Swadaya; 2008.
11. Nayak BS, Sandiford S, Maxwell A. Evaluation of the wound-healing activity of ethanolic extract of Morinda Citrifolia L. Leaf. Evid Base Complement Alternat Med 2009;6(3):351-6.

12. Hasanoglu A, Ara C, Ozen S, Kali K, Senol $M$, Ertas E. efficacy of micronized flavonoid fractionin heealing of clean and infected wounds. Int J Angiol 2001;10(1):41-4.

13. Kurnia PA, Ardhiyanto HB, suhartini. potensi ekstrak teh hijau (Camellia sinensis) terhadap peningkatan jumlah sel fibroblas soket pasca pencabutan gigi pada tikus Wistar. e-Jurnal Pustaka Kesehatan 2015;3(1).

14. Ardiana, Tifani, Kusuma, Andina RP, Firdausy, Muhammad D. Efektivitas pemberian gel Binahong (Anredera corfifolia) 5\% terhadap jumlah sel fibroblast pada soket pasca pencabutan gigi marmut (Cavia cobaya). Odonto Dent J 2015;2(1).

15. Chokotho L, van Hasselt $E$. the use of tannins in the local treatment of burn wounds-A pilot study. Malawi Med J 2005:7(1):19-20.

16. Soepriadi I. Regenerasi dan penyembuhan. Jakarta: Sagung Seto; 2013. p. 7-11.

17. Sabirin IP, Melani A, Hernowo BS. Peran ekstrak etanol topikal daun mengkudu (Morinda citrifolia L.) pada penyembuhan luka ditinjau dari imunoekspresi cd34 dan kolagen pada tikus galur Wistar. Cimahi: Fakultas Kedokteran Gigi Universitas Ahmad Yani 2013;45(4):226-33.

18. Komarruzaman AR, Permatasari N, Pasaribu R. Efektifitas ekstrak ginseng Asia (Panaxginseng) dalam meningkatkan jumlah pembuluh darah pada soket mandibula pasca pencabutan gigi (Rattus norvegicus). Majalah Kesehatan FKUB. 2015.

19. Yuhernita, Juniarti, Aryenti. Pengaruh Pemberian gel dari ekstrak metanol daun jarak tintir (Jatropha Multifida L) terhadap kepadatan serabut kolagen dan jumlah angiogenesis dalam proses penyembuhan luka. Jakarta: Prosiding Seminar Nasional dan Workshop "Perkembangan Terkini Sains Farmasi dan Klinik IV”. 2014. p. 47-55. 